\title{
Distribution, input pathway and mass inventory of black carbon in sediments of the Gulf of Thailand, SE Asia
}

\author{
Limin $\mathrm{Hu}^{\text {a, b, * }}{ }^{\text {, Xuefa Shi }}{ }^{\text {a, b, }{ }^{* *} \text {, Yazhi Bai }}{ }^{\text {a, b }}$, Yin Fang ${ }^{c}$, Yingjun Chen ${ }^{\text {c, d }}$, \\ Shuqing Qiao ${ }^{\text {a, b }}$, Shengfa Liu ${ }^{\text {a, b }}$, Gang Yang ${ }^{\text {a, b }}$, Narumol Kornkanitnan ${ }^{\text {e }}$, \\ Somkiat Khokiattiwong ${ }^{\mathrm{f}}$
}

${ }^{a}$ Key Laboratory of Marine Sedimentology and Environmental Geology, First Institute of Oceanography, State Oceanic Administration, Qingdao, 266061, China

b Laboratory for Marine Geology, Qingdao National Laboratory for Marine Science and Technology, Qingdao, 266061, China

${ }^{\mathrm{c}}$ Key Laboratory of Coastal Environmental Processes and Ecological Remediation, Yantai Institute of Coastal Zone Research, Chinese Academy of Science, Yantai, 264003, China

d Key Laboratory of Cities' Mitigation and Adaptation to Climate Change in Shanghai, College of Environmental Science and Engineering, Tongii University, Shanghai, 200092, China

e Marine and Coastal Resource Research Center, Samut Sakhon Province, 74000, Thailand

${ }^{f}$ Phuket Marine Biological Center, Muaeng Phuket, 83000, Thailand

\section{A R T I C L E I N F O}

\section{Article history:}

Received 30 July 2015

Received in revised form

27 November 2015

Accepted 21 December 2015

Available online 25 December 2015

\section{Keywords:}

Black carbon

Continental shelf sediments

Input pathway

Mass inventories

Gulf of Thailand

SE Asia

\begin{abstract}
A B S T R A C T
The coastal margins around Southeast Asia (SE Asia) may serve as an ideal location to study the sourcesink process of sedimentary black carbon (BC) because SE Asia has been identified as one of the major BC emission source regions in the world. This study provides an extensive picture of recent regional-scale sedimentary BC sequestration in the Gulf of Thailand (GOT), a tropical marine system in SE Asia. Generally, the sedimentary BC concentrations $(0.07-3.99 \mathrm{mg} / \mathrm{g})$ were in the low to moderate ranges of those obtained in other coastal sediments around the world. Regional variability of the $\mathrm{BC}$ and its correlation with the sediment grain size and total organic carbon (TOC) content indicated a general hydrodynamic constraint on $\mathrm{BC}$ occurrence in the lower Gulf in contrast to the upper Gulf with a more source dependence due to the direct land-based input. BC/TOC\% values and the varied BC components (char and soot), as well as their correlations suggested that char was the predominant constituents of sedimentary BC both in the upper and lower Gulf, which could be mainly derived from biomass burning and entered into the nearshore region through direct fluvial transport and surface run-off. The estimated BC burial flux $\left(\sim 212 \mu \mathrm{g} / \mathrm{cm}^{2} / \mathrm{y}\right)$ and mass inventory $(\sim 200 \mathrm{Gg} / \mathrm{y})$ in the GOT on the hundred-year timescale were of the same order of magnitude compared with other oceanic margins, and thus the tropical shelf sediments from SE Asia could serve as an important sink of land-emitted BC.
\end{abstract}

(C) 2015 Elsevier Ltd. All rights reserved.

\section{Introduction}

Black carbon (BC), including both the char and soot components, is usually defined as the recalcitrant carbonaceous residue

\footnotetext{
* Corresponding author. Key Laboratory of Marine Sedimentology and Environmental Geology, First Institute of Oceanography, State Oceanic Administration, Qingdao, 266061, China.

** Corresponding author. Key Laboratory of Marine Sedimentology and Environmental Geology, First Institute of Oceanography, State Oceanic Administration, Qingdao, 266061, China.

E-mail addresses: hulimin@fio.org.cn (L. Hu), xfshi@fio.org.cn (X. Shi).
}

produced from the incomplete combustion of biomass and fossil fuels (Goldberg, 1985; Schmidt and Noack, 2000; Baldock and Smernik, 2002; Dickens et al., 2004). The widespread combustion process and refractory nature make $\mathrm{BC}$ widely distributed in environmental matrices, such as the atmosphere, soils, fresh/sea water, ice and sediments. The emitted BC can eventually be transferred into the ocean through direct atmospheric deposition and river run-off by soil erosion (e.g., Goldberg, 1985; Suman et al., 1997; Gustafsson and Gschwend, 1998; Kuhlbusch, 1998; Mitra et al., 2002; Elmquist et al., 2008; Lohmann et al., 2009), which is an important process of the global carbon cycle as transferring the carbon from a rapidly cycling atmosphere-biosphere system into 
the long-term geological carbon pool (Seiler and Crutzen, 1980; Suman et al., 1997; Kuhlbusch, 1998; Middelburg et al., 1999). The interaction of $\mathrm{BC}$ among the various carbon pools is also relevant in predicting the climate change of the future earth (Bond et al., 2013).

It has been estimated that $290 \%$ of the marine BC deposition occurs on the marginal settings with the area less than $10 \%$ of the world ocean (Suman et al., 1997); however, the magnitude of the BC mass inventory in marine sediments on the global scale remains largely unknown (e.g., Gustafsson and Gschwend, 1998; Dickens et al., 2004; Masiello, 2004; Elmquist et al., 2008), which may be partially due to the scarcity of large-scale observations. Therefore, the extensive study of the BC occurrence and mass inventory in the continental margins is essential for a better understanding of the global biogeochemical cycle of $\mathrm{BC}$. However, a vast majority of the existing studies on the sedimentary BC in the coastal margins were geographically within high-latitude regions (e.g., Europe and America), such as the Northern European shelf (Sánchez-García et al., 2012), the Gulf of Cádiz (Sánchez-García et al., 2013), the Gulf of Maine (Gustafsson and Gschwend, 1998; Flores-Cervantes et al., 2009), the pan-arctic estuaries (Guo et al., 2004; Elmquist et al., 2008); the Washington coast (Dickens et al., 2004), etc., however, only little attention has been paid to the continental shelf of Asia (e.g., Wang and Li, 2007; Sun et al., 2008), particularly for the Southeast Asia (SE Asia), a tropical region, which has been identified as a major BC emission source region due to frequent forest fires, biomass burning and escalating fossil fuel utilisation (Streets et al., 2003). Moreover, the tropical coastal margins in SE Asia also serve as an important source emission region for coastal BC export due to the inherent nature of rapid transferring of land-based materials into the aquatic system via strong rain and surface runoff (Nittrouer et al., 1995; Zakaria et al., 2002; Saha et al., 2009). Therefore, the coastal sediments from tropical SE Asia may be an important reservoir for the exported BC from the adjacent landmass. Nevertheless, to date, the characterisation of sedimentary BC in these tropical regimes remains poorly understood.

The Gulf of Thailand (GOT), a shallow and semi-enclosed shelf sea in SE Asia, has been subjected to a huge BC emission from biomass burning, forest fires and fossil fuel consumption from the adjacent regions (Saha et al., 2009; Sahu et al., 2011; Huang et al., 2013). Because of the nutrient-rich, shallow waters and their confined nature, the ecosystem of the GOT is especially vulnerable to human activities (Srisuksawad et al., 1997), and increased anthropogenic activities around the GOT have induced severe environmental pollution, especially for the upper Gulf with significant river export of land-based contaminants (e.g., the Chao Phraya River) (Wattayakorn et al., 1998). Petroleum hydrocarbon contamination is evident in the nearshore waters of the GOT (Wattayakorn et al., 1998; Wattayakorn, 2012), and sedimentary polycyclic aromatic hydrocarbons (PAHs) exhibit a dominant river influence with mixed pyrogenic and petrogenic origins in the upper Gulf but with a dominant pyrogenic signature in the lower Gulf through atmospheric deposition (Boonyatumanond et al., 2006). This result may imply a different input pathway and source-sink processes for the combustion-derived substances (such as BC and PAHs) in the different GOT compartments (e.g., the upper vs. the lower Gulf).

In the present study, the large-scale occurrence of sedimentary $\mathrm{BC}$ and its mass inventory in the GOT was first examined to present a comprehensive study on BC abundance and its distribution pattern, input pathway and mass inventory in this tropical marginal system.

\section{Materials and methods}

\subsection{Study area and sediment sampling}

The Gulf of Thailand (GOT) is a shallow, semi-enclosed tropical marine embayment situated in the South China Sea, which is surrounded by the land mass of Malaysia, Thailand, Cambodia and Vietnam (Fig. 1). The GOT is relatively shallow with a mean depth of $45 \mathrm{~m}$ and a maximum depth of $80 \mathrm{~m}$. The Gulf can be usually divided into two parts, the upper Gulf and the lower Gulf (Fig. 1). The upper Gulf is the northernmost part of the GOT, covering approximately $10,000 \mathrm{~km}^{2}$ and receives a large amount of sewage, runoff and sediments, especially from the Chao Phraya River, which has a catchment area of $162,000 \mathrm{~km}^{2}$ and flows through several cities, including the mega-city of Bangkok (Wattayakorn et al., 1998; Boonyatumanond et al., 2006). The regional climate is generally warm and humid, with a typical southwest monsoon that prevails from May to September and a northeast monsoon that prevails from November to February. The induced seasonal circulation in the GOT is generally weak and variable (Wattayakorn et al., 1998; Wattayakorn, 2012), where an apparent counter-clockwise circulation occurs in the upper Gulf during the northeast monsoon, whereas both clockwise and counter-clockwise circulations occur during the southwest monsoon, depending on the wind conditions and external flow through the open boundary (Sojisuporn and Putikiatikajorn, 1998; Wattayakorn et al., 1998). The Gulf is poorly flushed on the whole, with little mixing, especially in the upper part (Wattayakorn et al., 1998), resulting in the majority of sediments and associated contaminants from the fluvial inputs primarily depositing in the upper Gulf (Srisuksawad et al., 1997). Sediment accumulation in the open GOT is mainly constrained by a combination of wind-driven currents, tides and its bottom topography (Takahashi et al., 1984). Muddy sediments mainly occur in the coastal area near the mouths of the major rivers in the upper Gulf, in addition to the central and western parts (near Samui Island) in the lower Gulf (Windom et al., 1982).

Ninety-three surface sediment samples were strategically collected on a regional-scale through three cruises conducted by $R /$ $V$ Boon-Lerd Pa-Sook and $R / V$ SEAFDEC 2 (SEAFDEC, i.e., Southeast Asian Fisheries Development Center) during 2010-2012. The samples were collected using a stainless steel box corer deployed from the vessels. All sediment samples $(0-3 \mathrm{~cm})$ were wrapped in pre-combusted aluminium foil and stored at $-20{ }^{\circ} \mathrm{C}$ until analysis.

\subsection{Analytical procedure}

Due to its complex organic and mineral matrices, the separation and quantification of $\mathrm{BC}$ in sediments is complicated, and several procedures have been developed for specific studies (Gustafsson et al., 1997, 2001; Song et al., 2002; Hammes et al., 2007; Han et al., 2007a, 2007b; Khan et al., 2009; Poot et al., 2009; Meredith et al., 2012; Wiedemeier et al., 2015). In the present work, the wet-chemical treatment combined with thermal/optical reflectance (TOR) detection was adopted (Han et al., 2007a, 2007b; Fang et al., 2015). Briefly, the thawed, freeze-dried and homogenized ( $<80$ meshes) sediment samples were treated with hydrochloric and hydrofluoric acids to remove inorganic materials. The acidtreated sediment residue was then filtered through precombusted quartz fibre filters (Whatman, $450{ }^{\circ} \mathrm{C}$ for $4 \mathrm{~h}$ and $47 \mathrm{~mm}$ in diameter). The filter samples were air dried and subsequently analysed for BC on a Desert Research Institute (DRI) Model 2001 Thermal/Optical Carbon Analyser (Atmoslytic Inc., Calabasas, CA) following the Interagency Monitoring of Protected Visual Environment (IMPROVE) protocols. A $0.544 \mathrm{~cm}^{2}$ circular punch drilled from the filter was placed in a quartz boat and then sent into an oven. During the carbon analysis, the oven was first heated in $100 \%$ He atmosphere, producing four OC fractions (OC1, OC2, OC3, and OC4) in four temperature steps $\left(140,280,480\right.$, and $\left.580{ }^{\circ} \mathrm{C}\right)$. Then, the analysis atmosphere was shifted to $2 \% \mathrm{O}_{2} / 98 \% \mathrm{He}$, and three EC fractions (EC1, EC2, and EC3) were produced in three 


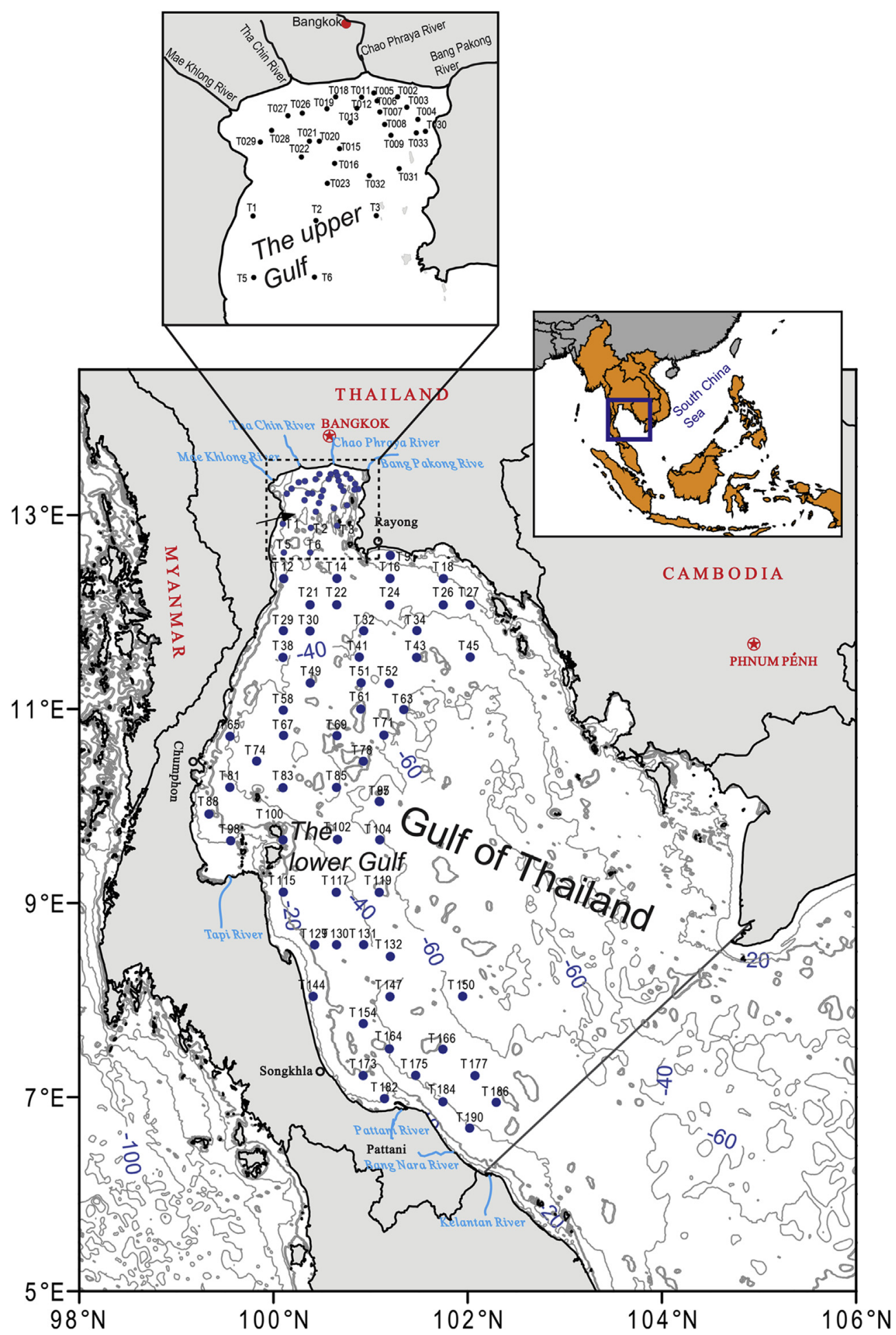

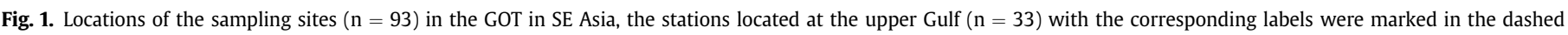
rectangle.

temperature steps $\left(580,740\right.$, and $\left.840^{\circ} \mathrm{C}\right)$. A portion of the volatilizable carbon chars in the absence of oxygen as indicated by the declined reflectance of the laser, which was termed "pyrolyzed organic carbon (POC)". Once in the oxidizing atmosphere, the POC evolve together with the original EC and leave the filter. The quantity of POC is defined as the carbon that evolves to the time at which the laser reflectance achieves its initial value (Han et al., 2007a). The IMPROVE protocol defined EC as the sum of the three $\mathrm{EC}$ sub-fractions minus the POC (i.e., $\mathrm{EC}=\mathrm{EC} 1+\mathrm{EC} 2+\mathrm{EC} 3-\mathrm{POC}$ ). Based on the finding that char and soot (two subtype of $\mathrm{BC}$ ) in standard reference materials can be stepwise oxidized in the EC1 and EC2 + EC3 steps, respectively, it was proposed that the IMPROVE method can be used to differentiate between char and soot, and char was defined as EC1 - POC, and soot as EC2 + EC3 
(Han et al., 2007b, 2015a). Detailed procedures for the BC separation and quantification are available in our recent work (Fang et al., 2015).

For quality assurance and quality control (QA/QC), whether the residue on the filters has an even distribution is a primary factor that markedly influences the accuracy of the BC concentration determination (Khan et al., 2009; Han et al., 2011; Fang et al., 2015). The typical filters loaded with acid-treated sediment residue are displayed in Fig. S1, and the residue on the filters has an even distribution to the naked eye. To confirm this distribution further, $10 \%$ of the total filters $(n=10)$ were randomly selected, and two punches drilled from different positions within a similar filter were analyzed for BC. The relative standard deviation (RSD, \%) of the measured $\mathrm{BC}$ concentration was in the range of $2-8 \%$, and averaged $4 \%$, fully demonstrating the even distribution of the residue on the filters.

Additionally, blank and replicate samples as well as standard reference material (NIST 1941b) were analyzed simultaneously at a frequency of one per ten samples. The blank samples $(n=10)$ yielded $0.00 \pm 0.00 \mu \mathrm{g} / \mathrm{cm}^{2}$ for $\mathrm{BC}$, and the RSD of 10 pairs of replicate analyses was in the range of $0-11 \%$, and averaged within $5 \%$. The BC concentration measured in SRM 1941b was $10.56 \pm 1.28 \mathrm{mg} / \mathrm{g}(\mathrm{n}=10)$, which was well in accordance with the values reported by recent studies (Hammes et al., 2007; Han et al., 2007a; Cong et al., 2013; Fang et al., 2015). These QA/QC results suggested that the $\mathrm{BC}$ analytical method used here was credible and repeatable (see Supplementary materials).

Detailed analytical methods for the TOC and sediment grain size were provided elsewhere (Hu et al., 2009, 2011). In brief, the grain size composition of each sample was determined using a Laser Particle Size Analyser (Mastersizer 2000, Malvern Instruments Ltd., UK). Portions of the sediment samples were treated with $4 \mathrm{M} \mathrm{HCl}$ to remove carbonates. The resulting carbonate-free samples were analysed for TOC in duplicate with a Vario EL-III Elemental Analyser.

\subsection{Estimation of the burial flux and mass inventory of the $B C$ in the GOT}

The burial flux and mass inventory of $\mathrm{BC}$ in this work were estimated according to the procedures from Tolosa et al. (1996); Hu et al. (2014). Briefly, the study area was divided into 93 homogenous sectors, with the sampling sites located in the centre of their respective sectors by coupling with the recent regional-scale varied sediment mass accumulation rates for each sample site (Fig. 7a, Srisuksawad et al., 1997). The BC burial flux $\left(\mu \mathrm{g} / \mathrm{cm}^{2} / \mathrm{y}\right)$ among each homogenous sector was estimated by the following equation:

$F_{i_{\text {burial }}}=C_{i} \cdot M_{i}$

where $\mathrm{Ci}$ is the BC concentration in the sediment sample of each sector, and $M i$ is the reported mass sediment accumulation rate among each divided sector (Srisuksawad et al., 1997).

The calculated $F i_{\text {burial }}$ is then applied to the corresponding areal extension of each divided sector to construct the $\mathrm{BC}$ mass inventory (I) in the study area according to the following equation:

$I=\sum_{i=1}^{93} C_{i} \cdot M_{i} \cdot A_{i}$

where $\mathrm{C} i$ is the BC concentration in the sediment sample of each sector, $M i$ is the reported mass sediment accumulation rate among each divided sector (Srisuksawad et al., 1997) and $A_{i}$ is the area of each divided sector.

\section{Results and discussion}

\subsection{Sediment grain-sizes and background depositional settings}

Surface sediments in the GOT primarily consisted of silt and sand silt with mean grain size (Mz) ranging from 11.5 to $547.6 \mu \mathrm{m}$ (mean, $52.9 \mu \mathrm{m}$ ) (Fig. 2a). Fine deposits predominantly occurred nearshore around the mouth of the major rivers from the upper Gulf and the central basin (Fig. 2b). The south of the Chao Phraya delta, the transition zone between the upper and lower Gulf, was mainly characterised as silty sand with coarser particle size $(>60 \mu \mathrm{m})$. The upper Gulf was mainly influenced by four rivers (the Chao Phraya, the Mae Klong, the Ta Chin and the Bang Pakong rivers) (Fig. 1), of which the total suspended sediments into the upper Gulf were estimated to be 6.32 million tons per year, but they were not efficiently transported southward into the central basin (Emery and Niino, 1963; Windom et al., 1982; Srisuksawad et al., 1997), resulting in relatively higher sediment accumulation rates in the upper Gulf (Windom et al., 1982; Srisuksawad et al., 1997). Water circulation and the depositional mechanism in the open GOT is complex and dominated by the combination of wind-driven currents, tides, density gradients and bottom topography (Takahashi et al., 1984). Even the sources and formation mechanism of the fine deposits in the central basin are not clear; the water circulation, inflowing and/or exchange with the open sea could be responsible for the depositional settings in the lower Gulf (Srisuksawad et al., 1997).

\subsection{Occurrence and spatial distribution of $B C$ and the potential controlling factors}

\subsubsection{Occurrence and distribution of $B C$ and TOC in the surface sediments}

The $\mathrm{BC}$ concentrations in the GOT ranged from 0.07 to $3.99 \mathrm{mg} / \mathrm{g}$ with a mean of $1.0 \pm 0.92 \mathrm{mg} / \mathrm{g}$ (Table 1 ). The BC content values in this work (measured by the IMPROVE_A TOR method; from Han et al., 2007a, 2007b) were in the low to moderate ranges of the BC concentrations obtained by different versions of the thermal methods in other coastal sediments around the world, such as the East China Seas $(<0.1-2.45 \mathrm{mg} / \mathrm{g}$, CTO method; Wang and Li, 2007; Kang et al., 2009), the Laizhou Bay in China $(0.02-1.29 \mathrm{mg} / \mathrm{g}$, TOR method; Fang et al., 2014), the Mexican margin $(0.9-2.6 \mathrm{mg} / \mathrm{g}$, modified CTO method; Gélinas et al., 2001), the Gulf of Maine (0.11-1.73 mg/g, CTO method; Gustafsson and Gschwend, 1998) and coastal Pakistan (0.6-2.5 mg/g, CTO method; Ali et al., 2014). The $\mathrm{BC}$ values were much lower than that from the Swedish continental shelf (0.58-17.66 mg/g, CTO method; Sánchez-García et al., 2012) (Table 1). The TOC content in the GOT showed a relatively wide range, varying between 1.8 and $29.3 \mathrm{mg} / \mathrm{g}$ (dry weight), and the BC accounted for $3.2-26.7 \%$ of the TOC with a mean of $10.8 \pm 4.9 \%$. The obtained $\mathrm{BC} / \mathrm{TOC} \%$ values in this work were relatively lower than those in other coastal sediments (up to $50 \pm 40 \%$ ), but comparable to those in abyssal sediments ( $15 \pm 2 \%$ to $21 \pm 6 \%)$ (Verardo and Ruddiman, 1996; Masiello and Druffel, 1998; Gustafsson and Gschwend, 1998; Lohmann et al., 2009; Coppola et al., 2014), revealing that the BC represents an important fraction of the sedimentary OC pool in the tropical marine system of SE Asia.

Spatially, higher BC values $(>1 \mathrm{mg} / \mathrm{g}$ ) were found in the nearshore of upper Gulf, the offshore regions over the central basin and the western part around the Sami Island (Fig. 3a). Pronounced low $\mathrm{BC}$ concentrations $(<0.3 \mathrm{mg} / \mathrm{g}$ ) were mainly found at the south of the Chao Phraya delta and the central and southern part of the lower Gulf. This spatial variability of BC generally displayed a similar pattern with that of sediment grain size (Fig. 2), 


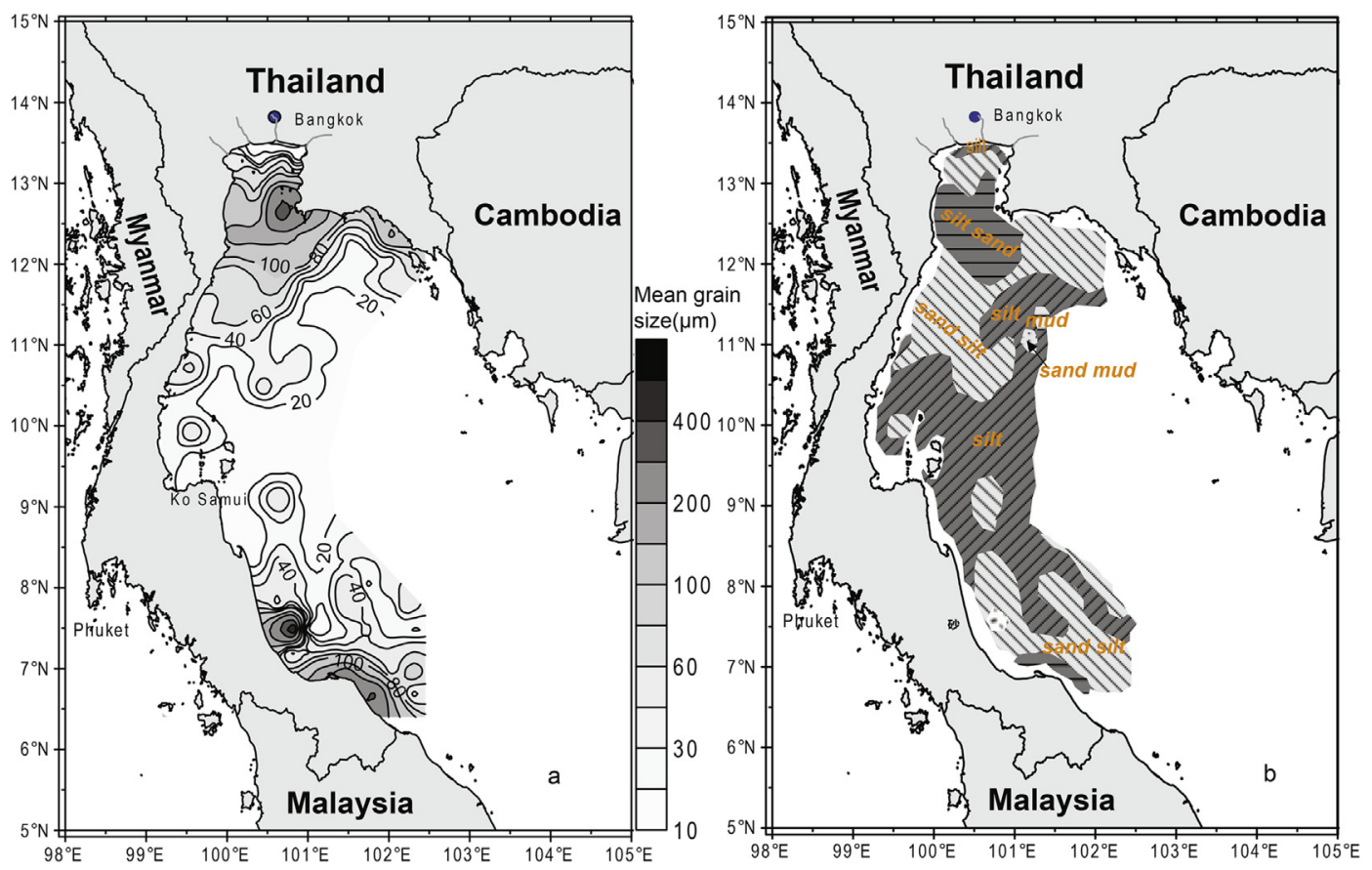

Fig. 2. Spatial distribution of the sediment grain size (a) and sediment types (b) in the GOT.
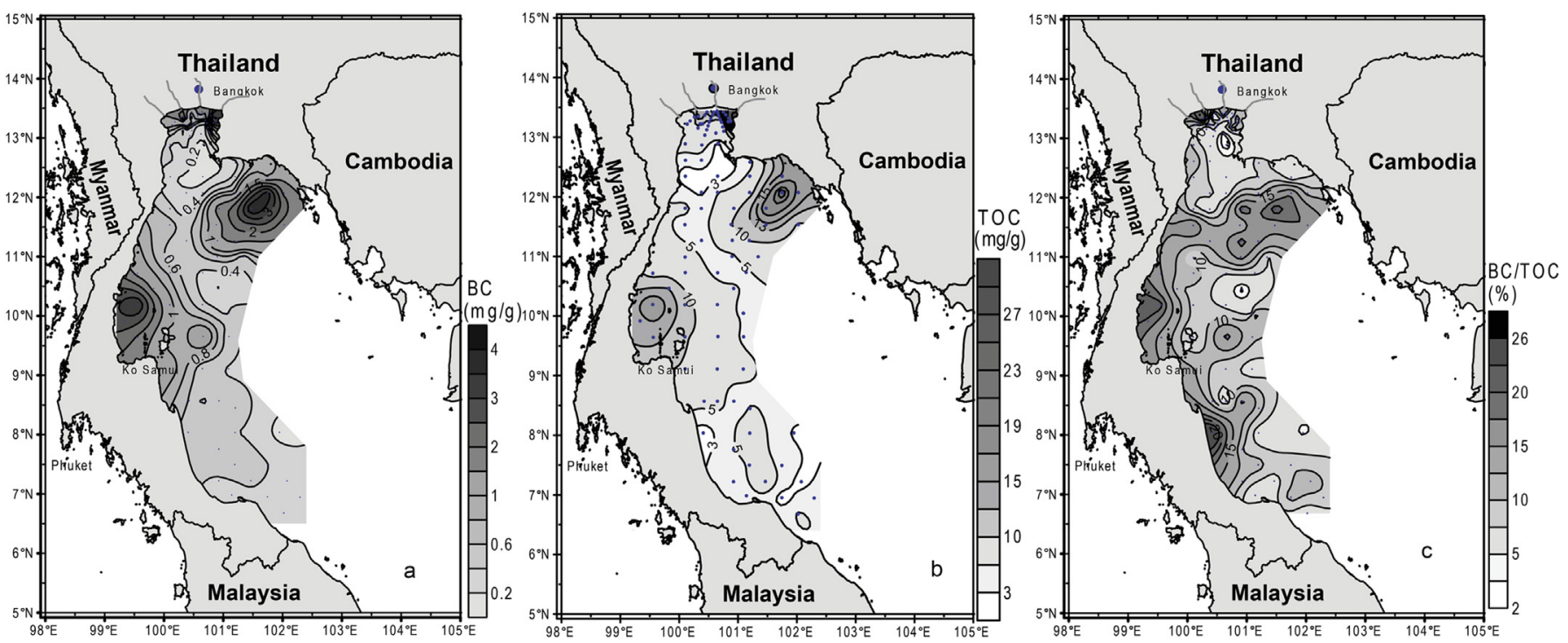

Fig. 3. Spatial distribution of the $B C$ abundance (a), TOC contents (b) and BC/TOC\% values (c).

indicating a potential influence of hydrodynamic condition on the BC accumulation. The TOC distribution in the GOT was also consistent with that of $\mathrm{BC}$, and the highest values were determined in the nearshore of the upper Gulf (Fig. 3b), where the mean TOC concentration was $11.8 \pm 7.0 \mathrm{mg} / \mathrm{g}$ compared to that of $7.2 \pm 4.5 \mathrm{mg} / \mathrm{g}$ in the lower Gulf, suggesting a more sourcedependent characteristic in the upper Gulf due to the direct fluvial inputs, in contrary to the more hydrodynamic constrains in the lower Gulf. Relatively higher BC/TOC\% values were mainly observed in the nearshore with proximity to the coast, which occurred not only in the upper Gulf, but also in the southern-most part of the lower Gulf (Fig. 3c). This finding could be related to the direct land-based input of $\mathrm{BC}$ in these areas through fluvial discharge and/or surface runoff. It has been suggested that terrigenous sediments and associated materials discharged by the coastal rivers in the upper Gulf were mainly constrained within the nearshore with limited offshore dispersion (Srisuksawad et al., 1997; Boonyatumanond et al., 2007); while the high values of BC/ TOC\% in the southern part of the nearshore in lower Gulf could be more determined by the lower TOC abundance (TOC $<3 \mathrm{mg} / \mathrm{g}$ ) with a steady concentration of $\mathrm{BC}$ in the sediments. The abrupt decrease of TOC concentration in these typical nearshore samples were more related to the intermittent extensive surface run-off owing to the heavy and frequent rain (Boonyatumanond et al., 2006), which could result in a large influx of heavier and/or large particles with limited TOC loading. 

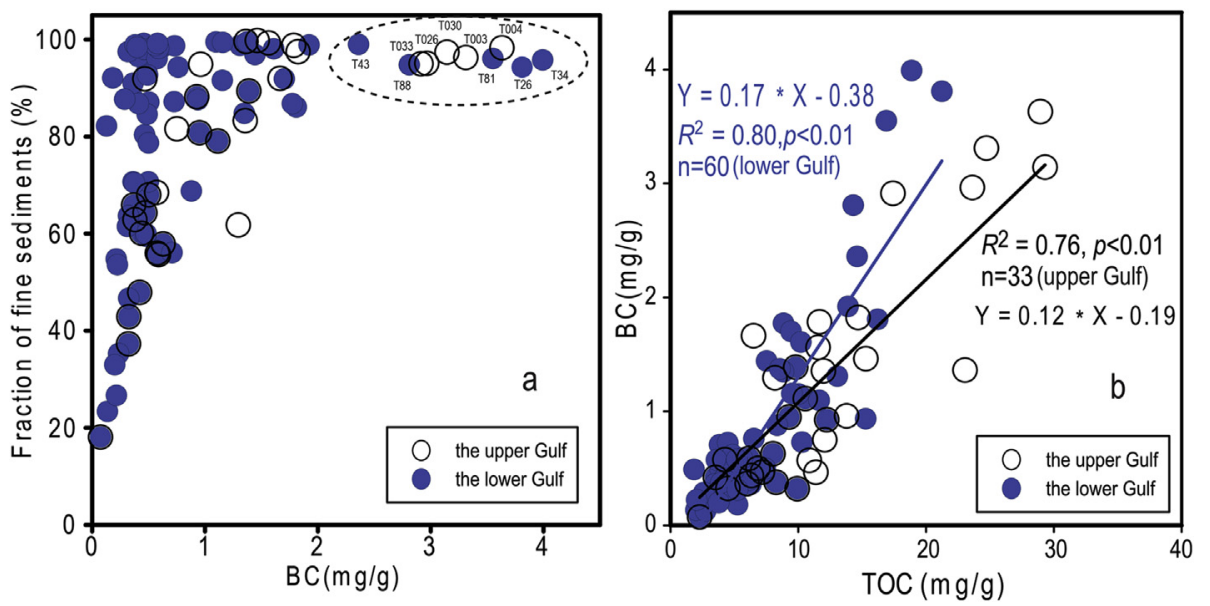

Fig. 4. The scatter plots of the BC abundance between sediment grain size (a) and TOC (b).
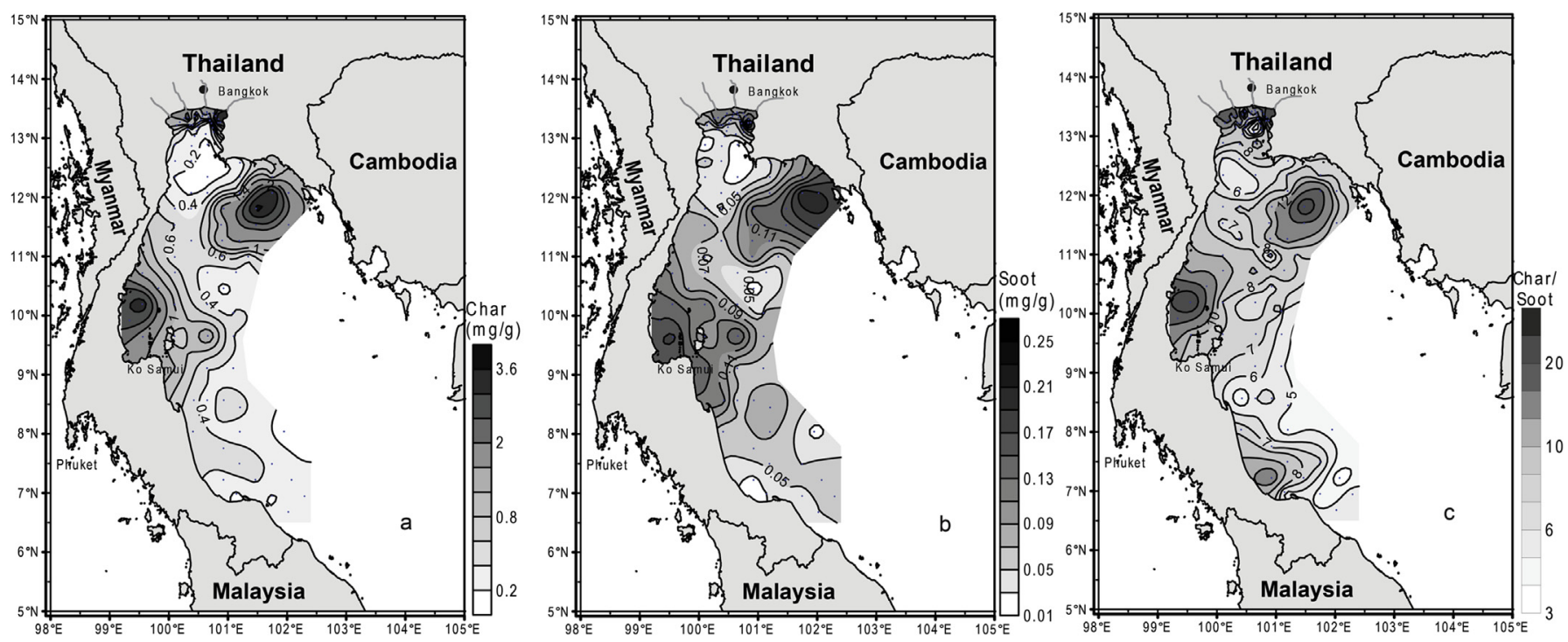

Fig. 5. Spatial distribution of the char (a) and soot (b) and their corresponding ratios (char/soot) (c).

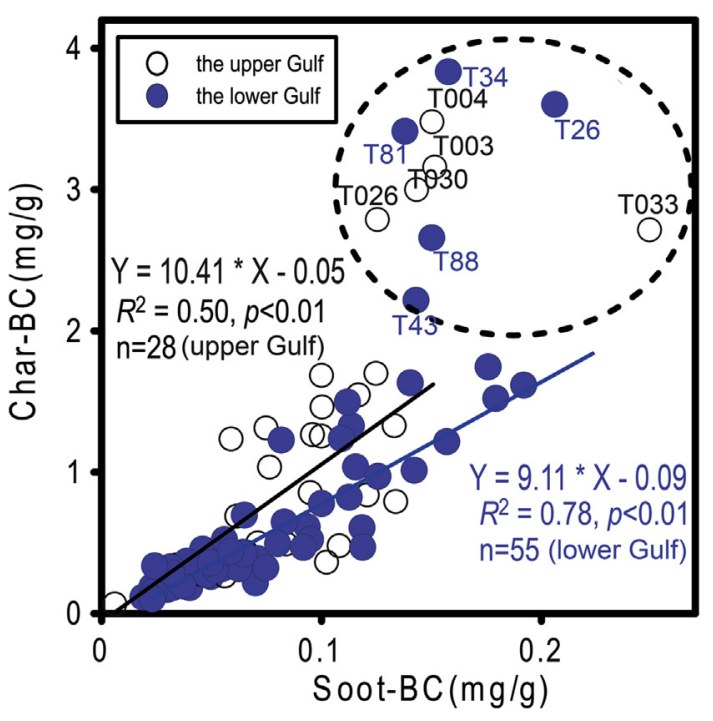

Fig. 6. The scatter plots of the correlation between char and soot components.

\subsubsection{Relationships between BC, TOC and sediment grain size and potential implications}

$\mathrm{BC}$ in the majority of the samples correlated with the sediment fine fraction (Fig. 4a), suggesting a general sorption control of the BC enrichment in fine-grained sediments; however, a separated grouping of the fine samples with relatively higher BC contents was observed and marked with the corresponding sites (Fig. 4a), and they were mainly from the river mouth in the coastal upper Gulf (e.g., sites T003, T004, T030) and from the eastern offshore area in central basin (e.g., sites T26, T34, T43). BC showed a significant and comparable correlation with TOC in the samples both from the upper and lower Gulf (Fig. 4b), reflecting a general hydrodynamic controls and/or their similar initial input pathways (e.g., land-based provenance). For the upper Gulf, the positive correlation between BC and TOC could be more related to the similar direct land-based input pathways, i.e., the extensive fluvial input and surface run-off from fired-impacted soils; while for the lower Gulf, this co-variance should be more explained by their coupled sedimentary dynamics caused by the high sorption and affinity of BC and TOC on the finer particles (e.g., Muri et al., 2003; Hu et al., 2014). This suggests that the hydrodynamic transport and depositional mechanism could 

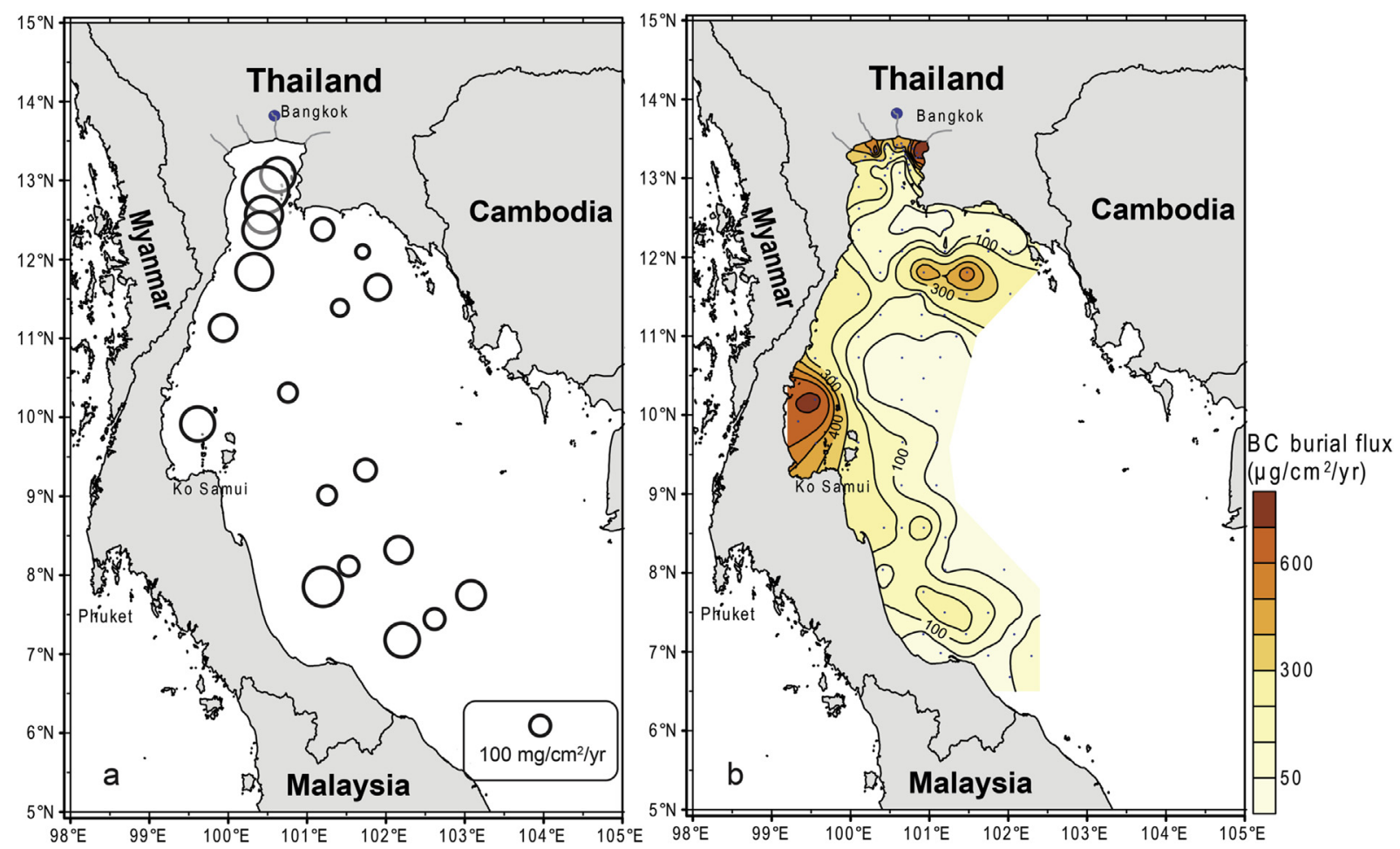

Fig. 7. Spatial distribution of the regional-scale recent sediment mass accumulation (from Srisuksawad et al., 1997) (a) and the BC burial flux (b) in the GOT.

Table 1

BC and TOC concentrations and BC burial flux in the Gulf of Thailand with comparison with other coastal margins around the world.

\begin{tabular}{|c|c|c|c|c|c|c|c|}
\hline \multirow[t]{2}{*}{ Study area } & \multicolumn{2}{|l|}{$\mathrm{C}_{\mathrm{BC}}(\mathrm{mg} / \mathrm{g})$} & \multicolumn{2}{|l|}{$\mathrm{C}_{\mathrm{TOC}}(\mathrm{mg} / \mathrm{g})$} & \multicolumn{2}{|c|}{$\mathrm{F}_{\text {burial of } \mathrm{BC}}\left(\mu \mathrm{g} / \mathrm{cm}^{2} / \mathrm{yr}\right)$} & \multirow[t]{2}{*}{ References } \\
\hline & Range & Mean & Range & Mean & Range & Mean & \\
\hline \multicolumn{8}{|l|}{ This study } \\
\hline Gulf of Thailand & $0.07-3.99$ & $1.01 \pm 0.93$ & $1.8-29.3$ & $8.8 \pm 5.9$ & $15-980$ & $212 \pm 228$ & This study \\
\hline The upper Gulf & $0.07-3.63$ & $1.23 \pm 0.97$ & $2.3-29.3$ & $11.8 \pm 7.0$ & $36-980$ & $336 \pm 259$ & This study \\
\hline The lower Gulf & $0.13-3.99$ & $0.89 \pm 0.88$ & $1.8-21.2$ & $7.2 \pm 4.5$ & $15-923$ & $144 \pm 178$ & This study \\
\hline \multicolumn{8}{|l|}{ Coastal margin settings } \\
\hline Coastal of Pakistan & $0.60-2.50$ & $0.65 \pm 0.46$ & $2.8-28.6$ & $11.7 \pm 6.4$ & $183-766$ & $330 \pm 155$ & Ali et al., 2014 \\
\hline Gulf of Cadiz, SW Spain & $0.10-1.10$ & $0.40 \pm 0.30$ & $5.0-14.0$ & $8.8 \pm 2.6$ & $42-285$ & $120 \pm 76$ & Sánchez-García et al., 2013 \\
\hline Swedish Continental Shelf & $0.58-17.66$ & $2.41 \pm 2.18$ & $4.8-168.0$ & $49.1 \pm 28.2$ & $267-8067$ & 1103 & Sánchez-García et al., 2012 \\
\hline Gulf of Maine, USA & $0.11-1.73$ & $0.65 \pm 0.46$ & $1.5-22.5$ & $12.7 \pm 6.6$ & $86-194$ & $131 \pm 38$ & Gustafsson and Gschwend, 1998 \\
\hline Mexican margin & $0.9-2.6$ & - & $17.6-79.9$ & - & - & - & Gélinas et al., 2001 \\
\hline East China Sea & $<0.1-2.45$ & $0.86 \pm 0.88$ & $3.0-44.4$ & $7.6 \pm 3.2$ & - & - & Kang et al., 2009 \\
\hline \multicolumn{8}{|l|}{ Pelagic regimes } \\
\hline Pacific Ocean & $0.01-0.99$ & $0.45 \pm 0.31$ & - & - & $0.002-0.2$ & $0.09 \pm 0.06$ & Smith et al., 1973 \\
\hline South Atlantic Ocean & $0.40-1.70$ & $1.02 \pm 0.26$ & $2.5-44.7$ & $14.1 \pm 12.3$ & $0.50-7.80$ & $2.27 \pm 1.73$ & Lohmann et al., 2009 \\
\hline Madeira Abyssal Plain & $0.74-2.85$ & $1.62 \pm 0.85$ & $1.8-11.4$ & $6.1 \pm 4.4$ & - & - & Middelburg et al., 1999 \\
\hline
\end{tabular}

also be an important factor affecting the occurrence of BC and TOC and their relationships, especially in the open GOT. Actually, this good correlation between $\mathrm{BC}$ and bulk OM was not only noticed in the particle phase (e.g., in soil, Glaser and Amelung, 2003; Cusack et al., 2012) but also in the dissolved phase and has been reported worldwide (e.g., Dittmar et al., 2012; Jaffé et al., 2013; Ding et al., 2013, 2015). The close relationship between BC and bulk OM in the dissolved phase could indicate that the release and subsequent sorption and desorption processes of $\mathrm{BC}$ are a complex function of environmental factors and particle properties, just as for bulk dissolved OM (Jaffé et al., 2013), which suggests that the mobilization of BC and bulk OM in various matrices is also mechanistically coupled.
It was however, also noticed, that the corresponding slope between TOC and BC in the upper Gulf were different from that of the lower part (Fig. 4b) as reflected by the lower percentage of $\mathrm{BC}$ in TOC in the upper Gulf $(\sim 12 \%, p<0.01)$ compared to that in the lower GOT $(\sim 17 \%, p<0.01)$. This difference could be explained as the following points: (1) the lower GOT has more significant input of soot-BC compared to the upper GOT (see below), which is served as the additional BC source and largely uncoupled from land-based sedimentary OM, resulting in the higher slope therein; (2) the different sedimentary OM pool in the upper and lower Gulf. Since phytoplankton production was reported to be a major contributor to the sedimentary OM pools in the lower Gulf (e.g., Meksumpun et al., 2005), the less refractory nature of marine OM 
thus may also be partly related to the varying slope observed in the lower GOT.

\subsection{Occurrence and input pathways of char and soot in the GOT}

Although BC is produced by incomplete combustion of fossil fuels and vegetation (Gustafsson and Gschwend, 1998; Schmidt and Noack, 2000), it is not a well-defined constituent, but a collective term, which refers to a combustion continuum and can be further divided into two subtypes of BC (i.e., char and soot) based on the temperature control in the analytical procedures (Masiello, 2004; Han et al., 2007b, 2015a). In this study, char and soot were measured using the IMPROVE thermal optical method according to Han et al. (2007b), which has been validated and successfully applied in aerosol studies (Han et al., 2010; Lim et al., 2012) and in soil and sediment studies (Han et al., 2009, 2011, 2015a, 2015b; Cong et al., 2013), in order to yield a better understanding of the distribution, sources and potential input pathways of char and soot within the tropical coastal system in SE Asia.

As shown in Fig. 5, the spatial variations of char and soot and their ratio values (char/soot) in the study area were presented and compared. The char/soot varied from 3.11 to 24.75 , with a mean value of $9.57 \pm 5.02$, indicating that char was a predominant constituent of BC in the GOT sediment samples. Char is produced mainly in a low-temperature combustion and has a large particle size (generally $1-100 \mu \mathrm{m}$ ), whereas the soot is mainly composed of submicrometer particles formed from the condensation of hydrocarbon radicals at high temperature combustion $\left(>600{ }^{\circ} \mathrm{C}\right.$ ) (Masiello, 2004; Han et al., 2011). Therefore, char is usually more related to the local biomass burning and industrial activities and is more easily incorporated into local soils and discharged into the adjacent aquatic sediments through rivers and surface run-off (Knicker et al., 2008). In the present study, char showed a more heterogeneous spatial pattern with several extreme high concentration values occurred in the nearshore area along the GOT (Fig. 5a); whereas soot concentrations and the corresponding char/soot ratios showed offshore decreased pattern (Fig. 5b and c).

Furthermore, the relationship between char and soot was in general less correlated in the upper Gulf with corresponding higher slopes (i.e., char/soot ratios) as compared to the lower Gulf (Fig. 6), which could be partially explained by a decoupling of the char and soot sources as noted above. Biomass burning and forest fires have been suggested to serve as the predominant sources for BC in aerosol samples in Thailand, especially in the hot season (Sahu et al., 2011), and the larger particles of char mainly from the biomass burning residues tend to first accumulate in soils in close proximity to their site of production and then be primarily transported by surface run-off and local river inputs to the aquatic sediments (Gélinas et al., 2001; Yunker et al., 2002; Pietzsch et al., 2010; Han et al., 2015a). Actually, in addition to the sedimentassociated BC, Ding et al. (2015) also demonstrated that there existed different input sources for the dissolved $\mathrm{BC}$ in the boreal forest streams through active removal process in soils from the local biomass burning as compared to those in the remote glacial rivers with a more atmospheric delivered fossil fuel-derived $\mathrm{BC}$. Above all, the occurrence of the composition of sedimentary $B C$ in the GOT in this work suggested that char as the predominant constituents of sedimentary BC both in the upper and lower Gulf could be mainly derived from biomass burning and it entered into the nearshore region mainly through fluvial transport and surface run-off from fire-impacted soils, as compared to the fossil fuel combustion-derived soot with a more ubiquitous atmospheric loading, especially in the lower Gulf. This point could also be supported by the high abundance of perylene in the coastal GOT that was originated from the direct terrestrial soil-derived material contribution (Boonyatumanond et al., 2006).

\subsection{Mass inventory of $B C$ in the GOT sediments and its comparison with other coastal regions around the world}

The BC burial flux over the GOT was estimated based on the measured BC abundances and reported mass sediment accumulation rates (Fig. 7a; from Srisuksawad et al., 1997). The spatial distribution of the BC burial flux showed an apparent regional viability (Fig. 7b), ranging from 15 to $980 \mu \mathrm{g} / \mathrm{cm}^{2} / \mathrm{y}$ with a mean of $212 \pm 228 \mu \mathrm{g} / \mathrm{cm}^{2} \cdot \mathrm{y}$. The highest BC burial flux was found in the upper Gulf with the average of $336 \mu \mathrm{g} / \mathrm{cm}^{2} \cdot \mathrm{y}$, significantly higher than that of the lower Gulf $\left(144 \mu \mathrm{g} / \mathrm{cm}^{2} / \mathrm{y}\right)$. In addition to the upper Gulf, the other two higher BC burial fluxes $\left(>300 \mu \mathrm{g} / \mathrm{cm}^{2} / \mathrm{y}\right)$ were concurrent within the finer deposits in the lower Gulf, indicating a potential depository for the land-based exported BC. The estimated $B C$ burial fluxes in this study were comparable with those of the coastal regimes around the world (Table 1), such as the Gulf of Cádiz $\left(120 \mu \mathrm{g} / \mathrm{cm}^{2} / \mathrm{y}\right)$ and the Gulf of Maine $\left(131 \mu \mathrm{g} / \mathrm{cm}^{2} / \mathrm{y}\right)$ (Gustafsson and Gschwend, 1998; Sánchez-García et al., 2013), but they were lower than those areas with strong human impact, such as the Swedish Continental Shelf $\left(1103 \mu \mathrm{g} / \mathrm{cm}^{2} / \mathrm{y}\right)$ (Sánchez-García et al., 2012). In contrast, this result was still 2-4 orders higher than those from the pelagic and deep sea sediment due to the relatively lower sedimentation rates, such as the Pacific deep sea (0.01-0.1 $\mu \mathrm{g} / \mathrm{cm}^{2} / \mathrm{y}$ ) (Smith et al., 1973) and the South Atlantic Ocean $\left(2.27 \mu \mathrm{g} / \mathrm{cm}^{2} / \mathrm{y}\right)$ (Lohmann et al., 2009).

Based on the estimated BC burial flux and accumulation areas of each of the divided homogenous sectors, the total mass inventory of depositional BC $\sim 200 \mathrm{Gg} / \mathrm{y}$ can be finally obtained for the $\sim 150,000 \mathrm{~km}^{2}$ of the study area. Considering the areal extension in the current work represents only half of the entire GOT $\left(\sim 320,000 \mathrm{~km}^{2}\right.$ in total), the estimated BC mass inventory in the GOT was on the same order of magnitude as other oceanic margins in the world, such as the New England continental shelf off northeastern USA $\left(400-800 \mathrm{Gg} / \mathrm{y}, \sim 380,000 \mathrm{~km}^{2}\right)$, the total South Atlantic Ocean (480-700 Gg/y, deep sea sediments) and the Swedish Continental Shelf $\left(\sim 300 \mathrm{Gg} / \mathrm{y}, \sim 155,342 \mathrm{~km}^{2}\right)$. For the subregions, the estimated sedimentary $\mathrm{BC}$ mass inventory for the upper Gulf $\left(\sim 7000 \mathrm{~km}^{2}\right)$ was $\sim 15 \mathrm{Gg} / \mathrm{y}$. The total suspended solids (TSS) delivered into the upper Gulf by the major four rivers have been estimated at 6.32 million tons per year (Srisuksawad et al., 1997); therefore, it could result in a riverine BC flux delivery of $\sim 12 \mathrm{Gg} / \mathrm{y}$ into the upper Gulf (if BC constituted $0.2 \%$ of TSS). This result partially supports that the riverine export is a predominant pathway for BC input in the coastal upper Gulf. For the lower Gulf, in spite of the influx of fluvial TSS was much less due to the relatively low water discharge (Simpson and Snidvongs, 1998), the significant land-based BC input through the extensive surface runoff could also be important, especially for the nearshore regions with obvious higher values of BC/TOC\% and char/soot ratios as noted above. Besides, the atmospheric delivery of combustionderived soot-BC could also serve an important role for the buried $\mathrm{BC}$ in the open GOT.

A major problem in quantifying BC is that it is not a well-defined chemical component, but rather exists as a complex concept of combustion/temperature continuum, with widely varying physical and chemical characteristics (Hedges et al., 2000; Masiello, 2004; Hammes et al., 2007; Conedera et al., 2009; Wiedemeier et al., 2015). Therefore, it is worth noting that the direct comparison as noted above was complicated considering the used different $\mathrm{BC}$ quantification methods with regard to the BC sources and sinks. Anyway, based on the same $\mathrm{BC}$ measurement procedures, the mass inventory of $\mathrm{BC}$ in the GOT in the present study was comparable 
with our recent work in the Bohai Sea $(\sim 147 \mathrm{Gg} / \mathrm{y})$ and the Yellow Sea $(\sim 171 \mathrm{Gg} / \mathrm{y})$ off the western Pacific margins (Fang et al., 2015). The semi-enclosed Bohai Sea and Yellow Sea, from the moderatehigh latitude region, are mainly situated at the downwind area of the East Asian Monsoon, receiving large amounts of combustionderived substances (e.g., PAHs) through atmospheric deposition, especially in the winter season due to the extensive regional heating activities in China (Wang et al., 2014). The surrounding region of the GOT from the tropical regime is more subjected to the extensive biomass burning, especially during the hot season (Sahu et al., 2011). Although there is no extensive coal consumption around the GOT, such as that in North China, the inherent biomass burning in tropical SE Asia is also significant (Bond et al., 2004), and atmospheric deposition is expected to be an important $B C$ vector for the Indian Ocean (Lohmann et al., 2009). Therefore, the atmospheric delivery of $\mathrm{BC}$ could play an important role in the regional $\mathrm{BC}$ budget in the open GOT, and the shelf sediments could serve as a significant depository of BC in the large-scale fate within SE Asia.

\section{Conclusions}

$\mathrm{BC}$ concentration in the GOT ranged from 0.07 to $3.99 \mathrm{mg} / \mathrm{g}$ and was comparable with those in other shelf settings around the world. Spatial variability of BC closely corresponded to sediment grain size and TOC content, suggesting a general hydrodynamic forcing on the $\mathrm{BC}$ occurrence in the open GOT in addition to the source-dependent control in the coastal region. Positive correlation between BC and TOC in the upper Gulf could be more related to their similar land-based input pathways; while this co-variance in the lower Gulf should be more explained by their coupled sedimentary dynamics. Char as the predominant constituents of sedimentary BC both in the upper and lower Gulf samples could be mainly derived from biomass burning and entered into the nearshore through fluvial transport and surface run-off, while the lower Gulf had a more significant input of soot compared to the upper Gulf. The estimated BC mass inventory in the GOT was $\sim 200 \mathrm{Gg} / \mathrm{y}$ and comparable with other shelf regimes, implying that the coastal margins in tropical SE Asia can serve as a significant reservoir for the exported $\mathrm{BC}$ from the adjacent landmass.

\section{Acknowledgements}

We thank Penjai Sompongchaiyakul from Chulalongkorn University for the assistance during field sampling. This work was supported by the Natural Science Foundation of China (NSFC) (Grant No. 41206055), National Programme on Global Change and Air-Sea Interaction (GASI-GEOGE-03; GASI-02-SCS-CJ03), Basic Scientific Fund for National Public Research Institutes of China (Grant No. GY0214G28) and the China-Thailand cooperation project "Research on Vulnerability of Coastal Zones". This work is also partly supported by Taishan Scholar Program of Shandong. The editors and anonymous reviewers should be sincerely appreciated for the constructive comments that greatly improved this study.

\section{Appendix A. Supplementary data}

Supplementary data related to this article can be found at http:// dx.doi.org/10.1016/j.ecss.2015.12.019.

\section{References}

Ali, U., Syed, J.H., Junwen, L., Sánchez-García, L., Malik, R.N., Chaudhry, M.J.I., Arshad, M., Li, J., Zhang, G., Jones, K.C., 2014. Assessing the relationship and influence of black carbon on distribution status of organochlorines in the coastal sediments from Pakistan. Environ. Pollut. 190, 82-90.

Baldock, J.A., Smernik, R.J., 2002. Chemical composition and bioavailability of thermally altered Pinus resinosa (Red pine) wood. Org. Geochem. 33, 1093-1109.

Bond, T.C., Streets, D.G., Yarber, K.F., Nelson, S.M., Woo, J.H., Klimont, Z., 2004. A technology-based global inventory of black and organic carbon emissions from combustion. J. Geophys. Res. Atmos. 109, D14203. http://dx.doi.org/ 10.1029/2003JD003697.

Bond, T.C., Doherty, S.J., Fahey, D., Forster, P., Berntsen, T., DeAngelo, B., Flanner, M., Ghan, S., Kärcher, B., Koch, D., 2013. Bounding the role of black carbon in the climate system: a scientific assessment. J. Geophys. Res. Atmos. 118, $5380-5552$.

Boonyatumanond, R., Wattayakorn, G., Togo, A., Takada, H., 2006. Distribution and origins of polycyclic aromatic hydrocarbons (PAHs) in riverine, estuarine, and marine sediments in Thailand. Mar. Pollut. Bull. 52, 942-956.

Boonyatumanond, R., Wattayakorn, G., Amano, A., Inouchi, Y., Takada, H., 2007. Reconstruction of pollution history of organic contaminants in the upper Gulf of Thailand by using sediment cores: first report from Tropical Asia core (TACO) project. Mar. Pollut. Bull. 54, 554-565.

Conedera, M., Tinner, W., Neff, C., Meurer, M., Dickens, A.F., Krebs, P., 2009. Reconstructing past fire regimes: methods, applications, and relevance to fire management and conservation. Quat. Sci. Rev. 28, 555-576.

Cong, Z., Kang, S., Gao, S., Zhang, Y., Li, Q., Kawamura, K., 2013. Historical trends of atmospheric black carbon on Tibetan Plateau as reconstructed from a 150-year lake sediment record. Environ. Sci. Technol. 47, 2579-2586.

Coppola, A.I., Ziolkowski, L.A., Masiello, C.A., Druffel, E.R., 2014. Aged black carbon in marine sediments and sinking particles. Geophys. Res. Lett. 41, 2427-2433.

Cusack, D.F., Chadwick, O.A., Hockaday, W.C., Vitousek, P.M., 2012. Mineralogical controls on soil black carbon preservation. Glob. Biogeochem. Cycles 26, 2019-2028.

Dickens, A.F., Gelinas, Y., Masiello, C.A., Wakeham, S., Hedges, J.I., 2004. Reburial of fossil organic carbon in marine sediments. Nature 427, 336-339.

Ding, Y., Yamashita, Y., Dodds, W.K., Jaffé, R., 2013. Dissolved black carbon in grassland streams: is there an effect of recent fire history? Chemosphere 90, 2557-2562.

Ding, Y., Yamashita, Y., Jones, J., Jaffé, R., 2015. Dissolved black carbon in boreal forest and glacial rivers of central Alaska: assessment of biomass burning versus anthropogenic sources. Biogeochemistry 123, 15-25.

Dittmar, T., de Rezende, C.E., Manecki, M., Niggemann, J., Ovalle, A.R.C., Stubbins, A., Bernardes, M.C., 2012. Continuous flux of dissolved black carbon from a vanished tropical forest biome. Nat. Geosci. 5, 618-622.

Elmquist, M., Semiletov, I., Guo, L., Gustafsson, Ö., 2008. Pan-Arctic patterns in black carbon sources and fluvial discharges deduced from radiocarbon and $\mathrm{PAH}$ source apportionment markers in estuarine surface sediments. Glob. Biogeochem. Cycles 22, GB2018,. http://dx.doi.org/10.1029/2007GB002994.

Emery, K.O., Niino, H., 1963. Sediments of the Gulf of Thailand and adjacent continental shelf. Geol. Soc. Am. Bull. 74, 541-554.

Fang, Y., Chen, Y.J., Lin, T., Pan, X.H., Tian, C.G., Tang, J.H., Li, J., Zhang, G., 2014 Distribution of black carbon and its correlation with persistent organic pollutants (POPs) in the surface sediments of coastal zone, Laizhou Bay (in Chinese). Geochimica 43, 329-337.

Fang, Y., Chen, Y.J., Tian, C.G., Lin, T., Hu, L.M., Huang, G., Tang, J.H., Li, J., Zhang, G. 2015. Flux and budget of BC in the continental shelf seas adjacent to Chinese high BC emission source regions. Glob. Biogeochem. Cycles 29, 957-972.

Flores-Cervantes, D.X., Plata, D.L., MacFarlane, J.K., Reddy, C.M., Gschwend, P.M., 2009. Black carbon in marine particulate organic carbon: inputs and cycling of highly recalcitrant organic carbon in the Gulf of Maine. Mar. Chem. 113, $172-181$.

Gélinas, Y., Prentice, K.M., Baldock, J.A., Hedges, J.I., 2001. An improved therma oxidation method for the quantification of soot/graphitic black carbon in sediments and soils. Environ. Sci. Technol. 35, 3519-3525.

Glaser, B., Amelung, W., 2003. Pyrogenic carbon in native grassland soils along a climosequence in North America. Glob. Biogeochem. Cycles 17. http:// dx.doi.org/10.1029/2002gb002019.

Goldberg, E.D., 1985. Black Carbon in the Environment: Properties and Distribution. John Wiley and Sons, New York.

Guo, L., Semiletov, I., Gustafsson, Ö., Ingri, J., Andersson, P., Dudarev, O., White, D. 2004. Characterization of Siberian Arctic coastal sediments: implications for terrestrial organic carbon export. Global Biogeochem. Cycles 18. GB1036.

Gustafsson, Ö., Gschwend, P.M., 1998. The flux of black carbon to surface sediments on the New England continental shelf. Geochim. Cosmochim. Acta 62, 465-472.

Gustafsson, Ö., Haghseta, F., Chan, C., MacFarlane, J., Gschwend, P.M., 1997. Quantification of the dilute sedimentary soot phase: implications for PAH Speciation and Bioavailability. Environ. Sci. Technol. 31, 203-209.

Gustafsson, Ö., Bucheli, T.D., Kukulska, Z., Andersson, M., Largeau, C., Rouzaud, J.N. Reddy, C.M., Eglinton, T.I., 2001. Evaluation of a protocol for the quantification of black carbon in sediments. Glob. Biogeochem. Cycles 15, 881-890.

Hammes, K., et al., 2007. Comparison of quantification methods to measure firederived (black/elemental) carbon in soils and sediments using reference materials from soil, water, sediment and the atmosphere. Glob. Biogeochem. Cycles 21, GB3016.

Han, Y.M., Cao, J.J., An, Z., Chow, J.C., Watson, J.G., Jin, Z., Fung, K., Liu, S., 2007a. Evaluation of the thermal/optical reflectance method for quantification of elemental carbon in sediments. Chemosphere 69, 526-533.

Han, Y.M., Cao, J.J., Chow, J.C., Watson, J.G., An, Z., Jin, Z., Fung, K., Liu, S., 2007b. Evaluation of the thermal/optical reflectance method for discrimination between char-and soot-EC. Chemosphere 69, 569-574. 
Han, Y.M., Cao, J.J., Posmentier, E., Chow, J., Watson, J., Fung, K., Jin, Z., Liu, S., An, Z., 2009. The effect of acidification on the determination of elemental carbon, char-, and soot-elemental carbon in soils and sediments. Chemosphere 75, 92-99.

Han, Y.M., Cao, J.J., Lee, S., Ho, K., An, Z., 2010. Different characteristics of char and soot in the atmosphere and their ratio as an indicator for source identification in Xi'an, China. Atmos. Chem. Phys. 10, 595-607.

Han, Y.M., Cao, J.J., Yan, B., Kenna, T., Jin, Z., Cheng, Y., Chow, J.C., An, Z., 2011 Comparison of elemental carbon in lake sediments measured by three different methods and 150-year pollution history in eastern China. Environ. Sci. Technol. 45, 5287-5293.

Han, Y.M., Bandowe, B.A.M., Wei, C., Cao, J.J., Wilcke, W., Wang, G.H., Ni, H.Y., Jin, Z.D., An, Z.S., Yan, B.Z. 2015a. Stronger association of polycyclic aromatic hydrocarbons with soot than with char in soils and sediments. Chemosphere 119, 1335-1345.

Han, Y.M., Wei, C., Bandowe, B.A.M., Wilcke, W., Cao, J.J., Xu, B.Q., Gao, S.P., Tie, X.X Li, G.H., Jin, Z.D., An, Z.S., 2015b. Elemental carbon and polycyclic aromatic compounds in a 150-year sediment core from lake Qinghai, Tibetan Plateau, China: influence of regional and local sources and transport pathways. Environ. Sci. Technol. 49, 4176-4183.

Hedges, J.I., Eglinton, G., Hatcher, P.G., Kirchman, D.L., Arnosti, C., Derenne, S., Evershed, R.P., Kögel-Knabner, I., de Leeuw, J.W., Littke, R., Michaelis, W., Rullkötter, J., 2000. The molecularly-uncharacterized component of nonliving organic matter in natural environments. Org. Geochem. 31, 945-958.

Hu, L.M., Guo, Z.G., Feng, J.L., Yang, Z.S., Fang, M., 2009. Distributions and sources of bulk organic matter and aliphatic hydrocarbons in surface sediments of the Bohai Sea, China. Mar. Chem. 113, 197-211.

Hu, L.M., Guo, Z.G., Shi, X.F., Qin, Y., Lei, K., Zhang, G., 2011. Temporal trends of aliphatic and polyaromatic hydrocarbons in the Bohai Sea, China: evidence from the sedimentary record. Org. Geochem. 42, 1181-1193.

Hu, L.M., Shi, X.F., Lin, T., Guo, Z.G., Ma, D.Y., Yang, Z.S., 2014. Perylene in surface sediments from the estuarine-inner shelf of the East China Sea: a potential indicator to assess the sediment footprint of large river influence. Cont. Shelf Res. 90, 142-150.

Huang, K., Fu, J.S., Hsu, N.C., Gao, Y., Dong, X., Tsay, S.-C., Lam, Y.F., 2013. Impact assessment of biomass burning on air quality in Southeast and East Asia during BASE-ASIA. Atmos. Environ. 78, 291-302.

Jaffé, R., Ding, Y., Niggemann, J., Vähätalo, A.V., Stubbins, A., Spencer, R.G., Campbell, J., Dittmar, T., 2013. Global charcoal mobilization from soils via dissolution and riverine transport to the oceans. Science 340, 345-347.

Kang, Y., Wang, X., Dai, M., Feng, H., Li, A., Song, Q., 2009. Black carbon and polycyclic aromatic hydrocarbons (PAHs) in surface sediments of China's marginal seas. Chin. J. Oceanol. Limnol. 27, 297-308.

Khan, A., Swami, K., Ahmed, T., Bari, A., Shareef, A., Husain, L., 2009. Determination of elemental carbon in lake sediments using a thermal-optical transmittance (TOT) method. Atmos. Environ. 43, 5989-5995.

Knicker, H., Hilscher, A., González-Vila, F.J., Almendros, G., 2008. A new conceptual model for the structural properties of char produced during vegetation fires. Org. Geochem. 39, 935-939.

Kuhlbusch, T., 1998. Black Carbon in Soils, Sediments, and Ice Cores. In: Meyers, R.A. (Ed.), Encyclopaedia of Environmental Analysis and Remediation. Wiley, New York, pp. 813-823.

Lim, S., Lee, M., Lee, G., Kim, S., Yoon, S., Kang, K., 2012. Ionic and carbonaceous compositions of PM 10, PM 2.5 and PM 1.0 at Gosan ABC superstation and their ratios as source signature. Atmos. Chem. Phys. 12, 2007-2024.

Lohmann, R., Bollinger, K., Cantwell, M., Feichter, J., Fischer-Bruns, I., Zabel, M., 2009. Fluxes of soot black carbon to South Atlantic sediments. Glob. Biogeochem. Cycles 23, GB1015,. http://dx.doi.org/10.1029/2008GB003253.

Masiello, C., 2004. New directions in black carbon organic geochemistry. Mar. Chem. 92, 201-213.

Masiello, C., Druffel, E., 1998. Black carbon in deep-sea sediments. Science 280, $1911-1913$.

Meksumpun, S., Meksumpun, C., Hoshika, A., Mishima, Y., Tanimoto, T., 2005. Stable carbon and nitrogen isotope ratios of sediment in the gulf of Thailand: evidence for understanding of marine environment. Cont. Shelf Res. 25, 1905-1915.

Meredith, W., Ascough, P., Bird, M., Large, D., Snape, C., Sun, Y., Tilston, E., 2012. Assessment of hydropyrolysis as a method for the quantification of black carbon using standard reference materials. Geochim. Cosmochim. Acta 97, 131-147.

Middelburg, J.J., Nieuwenhuize, J., van Breugel, P., 1999. Black carbon in marine sediments. Mar. Chem. 65, 245-252.

Mitra, S., Bianchi, T.S., McKee, B.A., Sutula, M., 2002. Black carbon from the Mississippi River: quantities, sources, and potential implications for the global carbon cycle. Environ. Sci. Technol. 36, 2296-2302.

Muri, G., Wakeham, S.G., Faganeli, J., 2003. Polycyclic aromatic hydrocarbons and black carbon in sediments of a remote alpine lake (Lake Planina, northwest Slovenia), Environ. Toxicol. Chem. 22, 1009-1016.

Nittrouer, C.A., Brunskill, G.J., Figueiredo, A.G., 1995. Importance of tropical coastal environments. Geo Marine Lett. 15, 121-126.

Pietzsch, R., Patchineelam, S.R., Torres, J.P., 2010. Polycyclic aromatic hydrocarbons in recent sediments from a subtropical estuary in Brazil. Mar. Chem. 118, 56-66.
Poot, A., Quik, J.T., Veld, H., Koelmans, A.A., 2009. Quantification methods of black carbon: comparison of rock-eval analysis with traditional methods. J. Chromatogr. A 1216, 613-622.

Saha, M., Togo, A., Mizukawa, K., Murakami, M., Takada, H., Zakaria, M.P., Chiem, N.H., Tuyen, B.C., Prudente, M., Boonyatumanond, R., Sarkar, S.K., Bhattacharya, B., Mishra, P., Tana, T.S., 2009. Sources of sedimentary PAHs in tropical Asian waters: differentiation between pyrogenic and petrogenic sources by alkyl homolog abundance. Mar. Pollut. Bull. 58, 189-200.

Sahu, L., Kondo, Y., Miyazaki, Y., Pongkiatkul, P., Kim Oanh, N., 2011. Seasonal and diurnal variations of black carbon and organic carbon aerosols in Bangkok. J. Geophys. Res. Atmos. 116, D15302,. http://dx.doi.org/10.1029/2010JD015563.

Sánchez-García, L., Cato, I., Gustafsson, Ö., 2012. The sequestration sink of soot black carbon in the Northern European shelf sediments. Glob. Biogeochem. Cycles 26, GB1001,. http://dx.doi.org/10.1029/2010GB003956.

Sánchez-García, L., de Andrés, J.R., Gélinas, Y., Schmidt, M.W.I., Louchouarn, P., 2013. Different pools of black carbon in sediments from the Gulf of Cádiz (SW Spain): method comparison and spatial distribution. Mar. Chem. 151, 13-22.

Schmidt, M.W., Noack, A.G., 2000. Black carbon in soils and sediments: analysis, distribution, implications, and current challenges. Glob. Biogeochem. Cycles 14 777-793.

Seiler, W., Crutzen, P.J., 1980. Estimates of gross and net fluxes of carbon between the biosphere and the atmosphere from biomass burning. Clim. Change 2, 207-247.

Simpson, J., Snidvongs, A., 1998. The influence of monsoonal river discharge on tropical shelf seas: the Gulf of Thailand as a case for study. In: Proceedings of the International Workshop on the Mekong Delta at Chiang Rai on 23-27 February 1998, pp. 86-99.

Smith, D.M., Griffin, J.J., Goldberg, E.D., 1973. Elemental carbon in marine sediments: a baseline for burning. Nature 241, 268-270.

Sojisuporn, P., Putikiatikajorn, P., 1998. Eddy circulation in the upper Gulf of Thailand from 2-D tidal model. In: Proceedings of the IOC/WESTPAC Fourth International Scientific Symposium, pp. 515-522.

Song, J., Peng, P.a, Huang, W., 2002. Black carbon and kerogen in soils and sediments. 1. Quantification and characterization. Environ. Sci. Technol. 36, 3960-3967.

Srisuksawad, K., Porntepkasemsan, B., Nouchpramool, S., Yamkate, P., Carpenter, R., Peterson, M.L., Hamilton, T., 1997. Radionuclide activities, geochemistry, and accumulation rates of sediments in the Gulf of Thailand. Cont. Shelf Res. 17, 925-965.

Streets, D., Bond, T., Carmichael, G., Fernandes, S., Fu, Q., He, D., Klimont, Z., Nelson, S., Tsai, N., Wang, M.Q., 2003. An inventory of gaseous and primary aerosol emissions in Asia in the year 2000. J. Geophys. Res. Atmos. 108, 8809,. http://dx.doi.org/10.1029/2002JD003093.

Suman, D., Kuhlbusch, T.A.J., Lim, B., 1997. Marine sediments: a reservoir for black carbon and their use as spatial and temporal records of combustion. In: Clark, J., Cachier, H., Goldammer, J., Stocks, B. (Eds.), Sediment Records of Biomass Burning and Global Change. Springer Berlin Heidelberg, pp. 271-293.

Sun, X., Peng, P.a, Song, J., Zhang, G., Hu, J., 2008. Sedimentary record of black carbon in the Pearl River estuary and adjacent northern South China Sea. Appl. Geochem. 23, 3464-3472.

Takahashi, K., Ruangsirakul, N., Rassmee, S., 1984. A comparative study on the fisheries oceanographic conditions in the central gulf of Thailand. In: SEAFDEC Current Technical Paper. TD/CTP/31.

Tolosa, I., Bayona, J.M., Albaiges, J., 1996. Aliphatic and polycyclic aromatic hydrocarbons and sulfur/oxygen derivatives in northwestern mediterranean sediments: spatial and temporal variability, fluxes, and budgets. Environ. Sci. Technol. 30, 2495-2503.

Verardo, D.J., Ruddiman, W.F., 1996. Late Pleistocene charcoal in tropical Atlantic deep-sea sediments: climatic and geochemical significance. Geology 24, 855-857.

Wang, X., Li, A., 2007. Preservation of black carbon in the shelf sediments of the East China Sea. Chin. Sci. Bull. 52, 3155-3161.

Wang, F., Lin, T., Li, Y., Ji, T., Ma, C., Guo, Z., 2014. Sources of polycyclic aromatic hydrocarbons in PM2. 5 over the East China Sea, a downwind domain of East Asian continental outflow. Atmos. Environ. 92, 484-492.

Wattayakorn, G., 2012. Petroleum pollution in the Gulf of Thailand: a historical review. Coast. Mar. Sci. 35, 234-245.

Wattayakorn, G., King, B., Wolanski, E., Suthanaruk, P., 1998. Seasonal dispersion of petroleum contaminants in the Gulf of Thailand. Cont. Shelf Res. 18, 641-659.

Wiedemeier, D.B., Brodowski, S., Wiesenberg, G.L., 2015. Pyrogenic molecular markers: linking PAH with BPCA analysis. Chemosphere 119, 432-437.

Windom, H., Paulsen, M., Hungspreugs, M., 1982. Rate of Sedimentation in the Upper Gulf of Thailand using the Lead-210 Method, pp. 8-10.

Yunker, M.B., Macdonald, R.W., Vingarzan, R., Mitchell, R.H., Goyette, D., Sylvestre, S., 2002. PAHs in the Fraser River basin: a critical appraisal of PAH ratios as indicators of PAH source and composition. Org. Geochem. 33, 489-515.

Zakaria, M.P., Takada, H., Tsutsumi, S., Ohno, K., Yamada, J., Kouno, E., Kumata, H., 2002. Distribution of polycyclic aromatic hydrocarbons (PAHs) in rivers and estuaries in Malaysia: a widespread input of petrogenic PAHs. Environ. Sci. Technol. 36, 1907-1918. 